\title{
Kolizyjnoprawna problematyka skuteczności przelewu wierzytelności wobec osób trzecich — projekt rozporządzenia Parlamentu Europejskiego i Rady w sprawie prawa właściwego dla skutków przelewu wierzytelności wobec osób trzecich (COM[2018) 96 final)
}

\begin{abstract}
The question of which law should govern the third-party effects of assignments of claims was considered during the preparation of the Rome I Regulation. The European Commission's proposal for the Rome I Regulation admitted the law of the assignor's habitual residence as the law that should apply to the proprietary effects of assignments of claims. Finally, EU Regulation on the law applicable to contractual obligations did not include the issue of the third-party effects of the assignment. However, Article 27(2) of the Rome I Regulation required the European Commission to present a report on the question of the effectiveness of assignments of claims against third parties accompanied, if appropriate, by a proposal to amend the Rome I Regulation. Proposal for a Regulation on the law applicable to the third-party effects of assignments of claims (COM(2018) 96 final) is a response to this request.

This paper analyses current draft of the new EU Regulation, the rules on determination of the third-party effects of assignments of claims (law of the assignor's habitual residence and law of the assigned claim) and „super conflict rules” in specific cases. The author argues that the law of the assignor's habitual residence remains the appropriate conflict rule for proprietary effects of assignments of claims.
\end{abstract}

Keywords: conflict of laws, assignment, the third-party effects of assignments, law applicable to the proprietary effects of assignments, contractual obligations, Rome I Regulation

a) Dr hab., prof. UŚ, Uniwersytet Ślaski w Katowicach. 


\section{Uwagi ogólne}

Przeniesienie wierzytelności z majątku cedenta na rzecz cesjonariusza pośrednio wywołuje skutki również wobec osób trzecich. Do tej grupy podmiotów zaliczany jest w pierwszej kolejności dłużnik, który, z reguły nie uczestnicząc $\mathrm{w}$ czynności prawnej powodującej przejście wierzytelności na nabywcę, może nie wiedzieć, na rzecz kogo powinien spełnić świadczenie, by zwolnić się z ciążącego na nim zobowiązania. Jednakże cesja wpływa także na pozycję prawną innych osób, dla których istotne jest, który z podmiotów - cedent czy też cesjonariusz - w danej chwili uważany jest za uprawnionego do otrzymania świadczenia ${ }^{1}$. Na płaszczyźnie merytorycznej chodzi — w odniesieniu do tej ostatniej grupy osób trzecich (z wyłączeniem dłużnika) - o rozstrzygnięcie kolizji między sprzecznymi interesami zainteresowanych $\mathrm{w}$ tym, by za wierzyciela uznać albo zbywcę, albo też nabywcę wierzytelności ${ }^{2}$. Paleta okoliczności, które moga wpływać na skuteczność cesji wobec osób trzecich jest szeroka. Przyjęciu prostego założenia, że przelew jest skuteczny erga omnes z chwila, gdy ma on wywołać skutki między stronami umowy cesji towarzyszą bowiem inne rozwiązania. Jako przykład można wskazać powiązanie skuteczności przeniesienia wierzytelności względem innych podmiotów od powiadomienia dłużnika o przelewie, wpisu transakcji do odpowiedniego rejestru czy też ogłoszenia o takim wpisie. Mnogość rozwiązań merytorycznych, jakie występuja w poszczególnych systemach prawnych, przekłada się na potrzebę ustalenia miarodajnego w tym zakresie statutu. Jednocześnie waga zagadnienia powoduje, że decyzja, jakiemu prawu poddać ocenę skuteczności przelewu wierzytelności wobec osób trzecich, nie jest łatwa.

Celem niniejszego opracowania jest przedstawienie krętej drogi, jaka przeszedł prawodawca unijny (a po trosze także i ustawodawca polski) w celu wypracowania kolizyjnoprawnych unormowań skuteczności przelewu wierzytelności wobec osób trzecich (innych niż dłużnik), jak również omówienie projektu rozporządzenia wieńczącego ten proces, ze wskazaniem wad i zalet przyjętych w nim rozwiązań.

${ }^{1}$ D. Einsele: Die Drittwirkung von Forderungsübertragungen im Kollisionsrechtein kritischer Zwischenruf zum Verordnungsvorschlag der Kommission, „IPRax” 2019, z. 6 , s. 477-478.

${ }^{2}$ Zob. szerzej W. Kurowski: Prawo wtaściwe do oceny skuteczności przelewu wierzytelności wobec osób trzecich, W: Znad granicy ponad granicami. Księga dedykowana Profesorowi Dieterowi Martiny, Red. M. Krzymuski, M. Margoński. Warszawa 2014, s. 155-156. 


\section{Rys historyczny kolizyjnoprawnego unormowania skutków przelewu wierzytelności wobec osób trzecich}

W polskich ustawach kolizyjnych, zarówno z 1926, jak i 1965 roku problematyka podmiotowych przekształceń stosunku zobowiazzaniowego nie była wyraźnie unormowania. Brak tam też było - co oczywiste wskazówki w zakresie prawa właściwego dla skuteczności cesji wobec osób trzecich. Sytuacja nie uległa zmianie w związku z wejściem w życie, a później - stosowaniem przez polskie sądy konwencji rzymskiej. Mimo bowiem wyraźnego wskazania w jej art. 12 prawa właściwego dla przelewu wierzytelności, omawiane zagadnienie pominięto milczeniem, co sprowokowało niekończace się spekulacje w tym zakresie. Co ciekawe, na etapie wstępnych prac nad konwencja rzymska, a ściśle - w art. 16 ust. 2 projektu konwencji o prawie właściwym dla zobowiązań umownych i pozaumownych z 1972 r. $^{3}$, rozważano poddanie skuteczności cesji wobec osób trzecich prawu przenoszonej wierzytelności, a ostateczna rozbieżność pomiędzy projektem konwencji z 1972 r. a jej ostateczną wersją bywała różnie interpretowana ${ }^{4}$. Dla jednych pominięcie tej kwestii w art. 12 konwencji rzymskiej było przejawem zwięzłości sformułowań, a zatem przepisy tego artykułu obejmowały także skuteczność cesji wobec osób trzecich ${ }^{5}$, natomiast dla innych - sytuacja ta stanowiła dowód

${ }^{3}$ Zob. m.in. M. Giuliano, W: M. Giuliano, P. Lagard, Th. van Sasse van Ysselt: Rapport concernant l'avant-projet de convention sur la loi applicable aux obligations contractuelles et non-contractuelles, „Rivista di diritto internazionale privato e processuale" 1973, Nr 1, s. 246-247; O. Lando: The EC Draft Convention on the Law Applicable to Contractual and Non-contractual Obligations, „Rabels Zeitschrift für ausländisches und internationales Privatrecht" [RabelsZ] 1974, Z. 1, s. 47 ; B. von Hoffmann: General Report on Contractual Obligations, W: European Private International Law of Obligations. Acts and documents of an International Colloquium on the European Preliminary Draft Convention on the Law Applicable to Contractual and Non-Contractual Obligations, held in Copenhagen on April 29 and 30, 1974. Red. O. Land , B. von Hoffmann, K. Siehr. Tübingen 1975, s. 27-28; L. Collins: Contractual Obligations - The EEC Preliminary Draft Convention on Private International Law, „The International and Comparative Law Quarterly" 1976, Vol. 25, s. 56; W. Kurowski: Przelew wierzytelności w prawie prywatnym miedzynarodowym. Kraków 2005, s. 59.

${ }^{4}$ A. Dickinson: Tough Assignments: the European Commission's Proposal on the Law Applicable to the Third-Party Effects of Assignments of Claims, „IPRax” 2018, z. 4, s. 338.

${ }^{5}$ D. Martiny, W: Internationales Vertragsrecht. Das internationale Privatrecht der Schuldverträge. Red. Ch. Reithmann, D. Martiny. Kolonia 1996, s. 294; M. Fallon, s. Francq: Les conflits de lois en matière d'obligations contractuelles et non contractuelles (1986-1997), „Journal des tribunaux“ 1998, s. 691; K. Siehr: Internationales Privatrecht. Deutsches und europäisches Kollisionsrecht für Studium und Praxis. Hei- 
dla tezy, zgodnie z którą w tym zakresie w konwencji rzymskiej występowała luka, dająca podstawy do dalszych poszukiwań kolizyjnych ${ }^{6}$. Sytuacja powtórzyła się przy pracach nad rozporządzeniem Rzym I. Wstępnie zaproponowano bowiem, by zagadnienie skuteczności cesji wobec osób trzecich wyraźnie unormować, poddając je prawu państwa, w którym zbywca wierzytelności ma swoje miejsce zwykłego pobytu w chwili dokonania transakcji. Ostatecznie jednak odstapiono od pomysłu, by w tekście rozporządzenia Rzym I taki przepis został ujęty. Nie ulega zatem wątpliwości, choćby w świetle omawianego projektu rozporządzenia, że problematyka skuteczności przelewu wierzytelności wobec osób trzecich nie znalazła ostatecznie swojego unormowania $\mathrm{w}$ rozporządzeniu Rzym I7.

delberg 2001, s. 234 (wskazani autorzy opowiadali się za objęciem zakresem normy kolizyjnej wynikającej z art. 12 ust. 2 konwencji rzymskiej także skuteczności cesji wobec osób trzecich).

${ }^{6}$ J. Foyer: Entrée en vigueur de la Convention de Rome du 19 juin 1980 sur la loi applicable aux obligations contractuelles, „Journal de droit international” 1991, Nr 3, s. 626; P. Lagarde: Le nouveau droit international privé des contrats après l'entrée en vigueur de la Convention de Rome du 19 juin 1980, „Revue critique de droit international privé" 1991, Nr 2, s. 335-336; T.H.D. Struycken: The proprietary aspects of international assignment of debts and the Rome Convention, Article 12, „Lloyd's Maritime and Commercial Law Quarterly" [LMCLQ] 1998, s. 349-350; J.A. Krupski: Connecting Security Rights in Receivables - A Canadian Perspective on the Rome Convention, „European Review of Private Law" 2002, Nr 6, s. 743-746; P. Lagarde: Retour sur la loi applicable à l'opposabilité des transferts conventionnels de créances, W: Droit et actualité. Etudes offertes à Jacques Béguin, Paris 2005, s. 418-419; W. Kurowski: Przelew wierzytelności..., s. 59; A. Wowerka: Prawo właściwe dla transakcji faktoringowych, „Problemy Prawa Prywatnego Międzynarodowego” [PPPM] 2009, T. 4, s. 144-146.

${ }^{7}$ S. Leible, M. Lehmann: Die Verordnung über das auf vertragliche Schuldverhältnisse anzuwendende Recht („Rom I”), „Recht der Internationalen Wirtschaft” [RIW] 2008, Z. 8, s. 541; F.J. Garcimartín Alférez: Assignment of claims in the Rome I Regulation: Article 14, W: Rome I Regulation. The Law Applicable to Contractual Obligations in Europe, Red. F. Ferrari, S. Leible. Monachium 2009, s. 234235; M.P. Zachariasiewicz: Zmiany w unormowaniu cesji wierzytelności (od artykułu 12 konwencji rzymskiej do artykuty 14 rozporzadzenia Rzym I), PPPM 2010, T. 6, s. 144 154; T.C. Hartley: Choice of law regarding the voluntary assignment of contractual obligations under the Rome I Regulation, „International and Comparative Law Quaterly” 2011, Nr 1, s. 46-56; A. Wowerka: Prawo właściwe..., s. 157 ; A. Wowerka: Przelew wierzytelności w świetle rozporzqdzenia Rzym I, PPPM 2011, t. 8, s. 44-53; W. Kurowski: Nowe kolizyjnoprawne unormowanie podmiotowych zmian stosunku zobowiazaniowego na tle rozporzadzenia „Rzym I” i polskiej ustawy - Prawo prywatne międzynarodowe z 2011 r., W: Wspótczesne wyzwania prawa prywatnego międzynarodowego. Red. J. Poczobut. Warszawa 2013, s. 146-147; W. Kurowski: Prawo właściwe..., s. 164. Zdanie odmienne w tym zakresie wyrazili m.in. A. Flessner, H.L.E. Verhagen: Assignment in European Private International Law. Claims as property and the European Commission's 'Rome I Proposal'. Monachium 2006, s. 24-26; H.L.E. Verhagen, S. van Dongen: Cross-border assignments under Rome I, „Journal of Private 
Istniejąca lukę $\mathrm{w}$ kolizyjnym unormowaniu podmiotowego przekształcenia stosunku zobowiązaniowego po stronie wierzyciela uzupełnił polski prawodawca ${ }^{8} \mathrm{w}$ art. $36 \mathrm{ppm}^{9}$. Jak się okazało, projektowana jako rozwiązanie przejściowe regulacja (przez to - jak się wydaje konserwatywna i nieprzystająca do realiów gospodarczych), stosowana jest z powodzeniem już przeszło osiem lat, a wiele wskazuje na to, że zastapiona zostanie przez odpowiednie unormowanie unijne po ponad dziesięciu latach od wejścia w życie rozporządzenia Rzym I. Nie ulega jednak wątpliwości, zważywszy na pewność obrotu, że w sytuacji gdy chodzi o ustalenie pierwszeństwa między konkurującymi podmiotami do wierzytelności będącej przedmiotem przelewu, pozostawienie tej kwestii nieunormowanej na płaszczyźnie kolizyjnej niosło za sobą więcej szkód niż pożytku. Nie znajduje tu bowiem zastosowania - przy sprzecznych interesach podmiotów, na których sytuacje prawną cesja wywiera wpływ - zasada no rule better than a bad rule. Co istotne, podobna droga, jak to miało miejsce $\mathrm{w}$ Polsce, podążyli także prawodawcy z innych państw unijnych, choć rozbieżności pomiędzy regulacjami kolizyjnymi były i sa nadal duże. I tak, w Belgii, we Francji oraz w Luksemburgu w odniesieniu do sekurytyzacji prawem właściwym do oceny skutków przelewu wierzytelności wobec osób trzecich jest prawo miejsca zwykłego pobytu cedenta. Z kolei w Hiszpani, podobnie jak w Polsce, dla omawianego zagadnienia stosowane jest prawo właściwe dla przelewanej wierzytelności ${ }^{10}$. Inne natomiast rozwiązanie przyjął prawodawca holenderski, poddając skuteczność przelewu erga omnes prawu właściwemu dla umowy zawartej między zbywca a nabywca wierzytelności.

Autorzy projektu rozporządzenia Rzym I również widzieli duże zagrożenie w braku jakichkolwiek norm kolizyjnych dotyczacych skuteczności przelewu wierzytelności wobec osób trzecich. Mimo zatem pozostawienia w końcowej wersji aktu luki w tym zakresie ${ }^{11}$, wprowa-

International Law 2010", Nr 1, s. 1-21; A. Flessner: Choice of Law in International Property Law - New Encouragement from Europe, W: Party Autonomy in International Property Law. Red. R. Westrik, J. van der Weide. Monachium 2011, s. 11-40; M. Czepelak: Międzynarodowe prawo zobowiazań Unii Europejskiej. Komentarz do rozporzqdzeń rzymskich. Warszawa 2012, s. 422-426.

${ }^{8}$ Ustawa z dnia z dnia 4 lutego 2011 r. - Prawo prywatne międzynarodowe (t.j. Dz.U. z 2015 r., poz. 1792) [dalej: ppm].

${ }^{9}$ A. Wowerka: Przelew wierzytelności..., s. 59-60; W. Kurowski: Nowe kolizyjnoprawne unormowanie..., s. 147.

${ }^{10}$ G. Cuniberti: La proposition de règlement de la Commission sur la loi applicable à l'opposabilité des cessions de créances, „Revue critique de droit international privé” 2018, T. 4, s. 793-794.

${ }^{11}$ R. Plender, M. Wilderspin: The European Private International Law of Obligations. London 2009, s. 386-387; F.J. Garcimartín Alférez: Assignment of 
dzili jednocześnie mechanizm mający na celu monitorowanie sytuacji, a w razie konieczności - podjęcie działań zmierzajacych do usunięcia niekorzystnych skutków pominięcia omawianej materii milczeniem. Zgodnie bowiem z art. 27 ust. 2 rozporządzenia Rzym I Komisja Europejska została zobowiązana do przedłożenia do dnia 17 czerwca 2010 roku Parlamentowi Europejskiemu, Radzie i Europejskiemu Komitetowi Ekonomiczno-Społecznemu sprawozdania na temat kwestii skuteczności przelewu wierzytelności (a także - traktowanej na płaszczyźnie kolizyjnej jednakowo - subrogacji umownej) wobec osób trzecich oraz kwestii pierwszeństwa przenoszonej wierzytelności przed prawami innych osób ${ }^{12}$. Sprawozdaniu temu miał towarzyszyć, w razie potrzeby, wniosek dotyczący zmiany rozporządzenia i ocena wpływu przepisów, które miałyby zostać wprowadzone. Zobowiązanie to nie było przez Komisje Europejska traktowane priorytetowo. Dopiero bowiem w 2011 roku zleciła British Institute of International and Comparative Law opracowanie raportu ${ }^{13}$, który stał się przyczynkiem do sprawozdania dla Parlamentu Europejskiego, Rady i Europejskiego Komitetu Ekonomiczno-Społecznemu na temat kwestii skutków przelewu lub subrogacji wierzytelności dla osób trzecich oraz kwestii pierwszeństwa przenoszonej wierzytelności przed prawami innych osób ${ }^{14}$. We wskazanym wcześniej raporcie ${ }^{15} \mathrm{Bri}$ tish Institute of International and Comparative Law sformułował kilka postulatów, z których jednak nieliczne zyskały aprobatę w kolejnych etapach prac nad projektem rozporządzenia w sprawie prawa właściwe-

claims..., s. 234-235; D. Martiny, W: Münchener Kommentar zum Bürgrlichen Gesetzbuch. Band 10. Red. H.J. Sonnenberger. Monachium 2010, s. 1059, 1070-1071; M.P. Zachariasiewicz: Zmiany $w$ unormowaniu cesji..., s. 144-154; A. Wowerka: Przelew wierzytelności..., s. 44-53; W. Kurowski: Nowe kolizyjnoprawne unormowanie..., s. 146-147; A. Dickinson: Tough Assignments..., s. 339.

${ }_{12}$ Zob. też P. Mankowski: Der Kommissionsvorschlag zum Internationalen Privatrecht der Drittwirkung von Zessionen, RIW 2018, Z. 8, s. 489-490; D. Einsele: Die Drittwirkung..., s. 477.

${ }^{13}$ British Institute of International and Comparative Law: Study on the question of effectiveness of an assignment or subrogation of a claim against third parties and the priority of the assigned or subrogated claim over a right of another person. Final report, s. $1-415$.

${ }^{14} \operatorname{COM}(2016) 626$ final.

${ }^{15}$ Raport British Institute of International and Comparative Law został omówiony m.in. przez E.-M. Kieninger: Das auf die Forderungsabtretung anzuwendende Recht im Licht der BIICL-Studie, IPRax 2012, Z. 4, s. 289-298; P. Mankowski: Zessionsgrundstatut $v$. Recht des Zedentensitzes - Ergänzende Überlegungen zur Anknüpfung der Drittwirkung von Zessionen, IPRax 2012, Z. 4, s. 298-306; S. Leible, M. Müller: Die Anknüpfung der Drittwirkung von Forderungsabtretungen in der Rom I-Verordnung, IPRax 2012, Z. 6, s. 491-500; R. Goode: The Assignment of Pure Intangibles in the Conflict of Laws, LMCLQ 2015, s. 303-313. 
go dla skutków przelewu wierzytelności wobec osób trzecich. W pierwszym rzędzie zaproponowano, by wskazana regulacja została włączona do rozporządzenia Rzym I, uzupełniając w tym zakresie treść obecnego art. 14 tego aktu. Poza tym sugerowano wyraźne rozdzielenie materii obligacyjnej $\mathrm{w}$ ramach relacji łączącej cedenta i cesjonariusza (regulowanej przez art. 3 rozporządzenia) od skuteczności erga omnes samego przelewu (tak pomiędzy cedentem i cesjonariuszem, jak i względem osób trzecich), a w tym celu - modyfikację obecnie obowiąującego art. 14 rozporządzenia Rzym I. W odniesieniu do reguł kolizyjnych dotyczących skuteczności przelewu wobec osób trzecich British Institute of International and Comparative Law zalecał - w zakresie, w jakim jest to tylko możliwe - wstrzemięźliwość w mnożeniu przepisów odnoszących się do specyficznych sytuacji, na rzecz stworzenia regulacji uniwersalnej, która jednocześnie będzie chronić interesy wszystkich zainteresowanych podmiotów $^{16}$. W raporcie wskazano przy tym trzy warianty unormowania przedmiotowego zagadnienia. Po pierwsze, za miarodajne w tym zakresie miałoby być prawo właściwe dla umowy wiążącej zbywcę i nabywcę wierzytelności (tj. prawo, jakiemu podlega relacja łącząca cedenta z cesjonariuszem). Drugim, wchodzącym w grę rozwiązaniem, mogłoby być poddanie omawianego zagadnienia prawu, któremu podlega przenoszona wierzytelność (tj. prawo właściwe dla stosunku wiążącego cedenta z dłużnikiem). Alternatywnie, dla wyznaczania prawa właściwego dla skutków przelewu wierzytelności wobec osób trzecich można by także posłużyć się łącznikiem miejsca zwykłego pobytu cedenta ${ }^{17}$.

W sprawozdaniu Komisji Europejskiej dla Parlamentu Europejskiego, Rady i Europejskiego Komitetu Ekonomiczno-Społecznego na temat kwestii skutków przelewu lub subrogacji wierzytelności dla osób trzecich oraz kwestii pierwszeństwa przenoszonej wierzytelności przed prawami innych osób z 2016 roku podniesiono z kolei, że unormowanie problematyki skuteczności cesji wobec osób trzecich, w tym kwestii pierwszeństwa między nabywcami lub między nabywcami i innymi podmiotami mającymi równoległe uprawnienia, zwiększyłoby pewność prawa oraz ograniczyłoby koszty wynikające $\mathrm{z}$ odmienności regulacji prawnych $\mathrm{w}$ poszczególnych państwach Unii Europejskiej. W konkluzji sprawozdania zarekomendowano, podobnie jak to miało miejsce w raporcie British Institute of International and Comparative Law, trzy potencjalnie sposoby regulacji wskazanej problematyki, opierajace się na stosowaniu w różnych wariantach - w zakresie skuteczności przelewu wobec osób trze-

${ }^{16}$ British Institute of International and Comparative Law: Study on the question..., s. 17 .

${ }^{17}$ British Institute of International and Comparative Law: Study on the question..., s. $406-415$. 
cich - prawa, któremu podlega umowa pomiędzy cedentem i cesjonariuszem, prawa przenoszonej wierzytelności albo prawa państwa, w którym zbywca ma miejsce zwykłego pobytu.

\section{Uwagi ogólne o projekcie rozporządzenia w sprawie prawa właściwego dla skutków przelewu wierzytelności wobec osób trzecich}

Efektem prac, których podstawą był wskazany wcześniej art. 27 ust. 2 rozporządzenia Rzym I, raport British Institute of International and Comparative Law oraz sprawozdanie Komisji Europejskiej z 2016 roku, jest projekt rozporządzenia w sprawie prawa właściwego dla skutków przelewu wierzytelności wobec osób trzecich, opracowany i przedstawiony przez Komisję Europejska w marcu 2018 roku $^{18}$.

Wbrew wcześniejszym oczekiwaniom, nowa regulacja nie ma modyfikować rozporządzenia Rzym I (poprzez wprowadzenie dodatkowego ustępu do art. 14 tego aktu), a uzupełniać istniejący stan prawny jako odrębne, a przy tym rozbudowane rozporządzenie ${ }^{19}$. W związku z powyższym konieczne stało się wyraźne określenie zakresu zastosowania regulacji (na wzór art. 1 rozporządzenia Rzym I), promulgowanie zasady powszechnego stosowania tego aktu (jak w art. 2 rozporządzenia Rzym I), czy też - już zwyczajowo - wprowadzenie mechanizmów ochronnych w postaci dopuszczenia stosowania przepisów wymuszających, czy też zabezpieczenia ordre public, jak również — wyłączenie odesłania (art. 6-8 projektu $)^{20}$. W związku z przyznaniem rozporządzeniu samodzielnego bytu, konieczne było opracowanie przepisów o charakterze porządkowo-organizacyjnym, dotyczacych stosowania tego aktu w państwach członkowskich posiadajacych niejednolity system prawny, stosunku nowego unormowania do innych przepisów unijnych regulujących w sposób szczególny problematykę skutków przelewu wierzytelności wobec osób trzecich, stosunku rozporządzenia do konwencji międzynarodowych, których stronami są państwa członkowskie, wprowadzenia klauzuli prze-

${ }^{18} \mathrm{COM}(2018) 96$ final.

${ }^{19} \mathrm{O}$ przesłankach opracowania projektu rozporządzenia zob. m.in. A. Dickinson: Tough Assignments..., s. 338-339.

${ }^{20}$ P. Mankowski: Der Kommissionsvorschlag..., s. 500-501; A. Dickinson: Tough Assignments..., s. 340. 
glądowej, nakładającej na Komisję Europejską obowiązek przedłożenia Parlamentowi Europejskiemu, Radzie i Europejskiemu Komitetowi Ekonomiczno-Społecznemu sprawozdania dotyczącego stosowania rozporzadzenia. Co oczywiste, niezbędne stały się także przepisy odnoszące się do kwestii intertemporalnych i wejścia w życie tego aktu. Najistotniejsze, a co za tym idzie - godne uwagi, sa natomiast przepisy określające prawo właściwe do oceny skutków przelewu wobec osób trzecich (art. 4), wyznaczajace zakres stosowania prawa właściwego (art. 5) oraz wprowadzające definicje pojęć występujących w rozporządzeniu (art. 2) ${ }^{21}$.

Już w tym miejscu warto wskazać, że projekt rozporządzenia szeroko ujmuje pojęcie „przelewu” ${ }^{22}$ ( $\mathrm{w}$ niniejszym opracowaniu zamiennie stosowane obok określenia „cesja”). Obejmuje ono bowiem tak bezwarunkowe przeniesienie wierzytelności, subrogację umowna, przeniesienie wierzytelności na zabezpieczenie, jak i ustanowienie zastawu lub innego zabezpieczenia na wierzytelności (art. 2 lit. c) $)^{23}$. Sformułowanie „wierzytelność" oznacza z kolei prawo do dochodzenia każdej wierzytelności, o charakterze pieniężnym lub niepieniężnym, wynikającej z zobowiązania umownego lub pozaumownego (art. 2 lit. d)). Autorzy projektu rozporządzenia zadbali zatem, by nowa regulacja była uniwersalna i stanowiła uzupełnienie wcześniejszych unormowań kolizyjnych (w szczególności rozporządzeń Rzym I i Rzym II, określających prawo właściwe dla potencjalnych źródeł przenoszonych wierzytelności oraz samej cesji).

\section{Zakres zastosowania rozporządzenia w sprawie prawa właściwego dla skutków przelewu wierzytelności wobec osób trzecich}

W związku z koniecznością zapewnienia komplementarności nowej regulacji skuteczności przelewu wobec osób trzecich z unormowaniami rozporządzeń: Rzym I i Rzym II, jak również rozporządzeniem jurysdykcyjnym nr 1215/2012 oraz rozporządzeniem nr 2015/848 w sprawie postępowania upadłościowego ${ }^{24}$, omawiany projekt rozporządzenia

${ }^{21}$ A. Dickinson: Tough Assignments..., s. 339.

${ }^{22}$ G. Cuniberti: La proposition de règlement..., s. 799.

${ }^{23}$ Podobnie art. 14 ust. 3 rozporządzenia Rzym I.

${ }^{24}$ Rozporządzenie Parlamentu Europejskiego i Rady (UE) 2015/848 z dnia 20 maja 2015 r. w sprawie postępowania upadłościowego, Dz.U. L 141 z 5.06.2015 r., s. 19—72 [dalej: rozporządzenie w sprawie postępowania upadłościowego]. 
znajdzie zastosowanie do skutków przelewu wierzytelności wobec osób trzecich $\mathrm{w}$ sprawach cywilnych i handlowych powiązanych $\mathrm{z}$ prawem różnych państw. W celu usunięcia watpliwości, podobnie jak to miało miejsce przy innych regulacjach kolizyjnych, wyraźnie wskazano, że rozporządzenie nie będzie stosowane w szczególności do spraw skarbowych, celnych i administracyjnych (art. 1 ust. 2). Z zakresu jego zastosowania wyłaczono także przelewy wierzytelności, co prawda o charakterze cywilnoprawnym (ewentualnie handlowym), jednakże wynikające ze stosunków rodzinnych oraz stosunków uznawanych za wywołujące podobne skutki, $\mathrm{w}$ tym $\mathrm{z}$ zobowiązań alimentacyjnych, wierzytelności wynikających z małżeńskich ustrojów majątkowych, z ustrojów majątkowych w stosunkach uznawanych za wywołujace podobne skutki do małżeństwa oraz $\mathrm{z}$ prawa spadkowego, w tym z testamentów, wierzytelności z weksli, czeków, weksli własnych oraz innych zbywalnych papierów wartościowych, wierzytelności wynikających ze stosunków wchodzących w zakres prawa spółek, wierzytelności związanych z tworzeniem trustów oraz stosunków prawnych pomiędzy założycielami, powiernikami i beneficjentami, jak również wierzytelności wynikających z umów ubezpieczenia zawartych w ramach operacji przeprowadzanych przez organizacje niebędace zakładami, o których mowa w art. 2 ust. 1 i 3 dyrektywy 2009/138/WE w sprawie podejmowania i prowadzenia działalności ubezpieczeniowej i reasekuracyjnej (Wypłacalność II) ${ }^{25}$, oraz wierzytelności, których przedmiotem jest zapewnienie pracownikom lub osobom pracującym na własny rachunek, należącym do zakładu lub grupy zakładów, lub do określonej grupy lub grup zawodowych, świadczeń w przypadku śmierci lub dożycia określonego wieku, przerwania lub ograniczenia działalności, choroby zawodowej lub wypadku przy pracy. Zabieg ten jest celowy. Skoro bowiem takie samo wyłaczenie zawiera art. 1 ust. 2 rozporządzenia Rzym I, a zatem jego przepisy nie stanowią podstawy do wyznaczania statutu przelewu określonych w tym zbiorze wierzytelności, nie sposób - zakładając komplementarność regulacji - normować $\mathrm{w}$ omawianym projekcie rozporządzenia problematyki skuteczności takiego przelewu wobec osób trzecich, jako kwestii cząstkowej.

${ }^{25}$ Dyrektywa Parlamentu Europejskiego i Rady 2009/138/WE z dnia 25 listopada 2009 r. w sprawie podejmowania i prowadzenia działalności ubezpieczeniowej i reasekuracyjnej (Wypłacalność II), Dz.U. L 335 z 17.12.2009 r., s. 1-155. 


\section{Prawo właściwe do oceny skuteczności przelewu wierzytelności wohec osób trzecich}

W projekcie rozporządzenia sięgnięto po trzy łączniki (subiektywny oraz dwa obiektywne), które maja stanowić podstawę wskazania prawa właściwego do oceny skutków cesji wobec osób trzecich, w zależności od tego, o przelew jakiej wierzytelności chodzi. Autorzy projektu przyjęli przy tym koncepcję, zgodnie z którą reguła ogólna powinna znaleźć zastosowanie wówczas, gdy przenoszona wierzytelność nie należy do wyraźnie określonych kategorii; w tych bowiem przypadkach trzeba sięgnać po unormowania szczególne. W związku z tak ukształtowaną regulacja, te ostatnie rozwiązania należy omówić w pierwszej kolejności. Jedynie tytułem wprowadzenia można w tym miejscu zasygnalizować, że co do zasady - a zatem jest to reguła ogólna - problematyka skuteczności przelewu wobec osób trzecich podlega prawu państwa, w którym zbywca wierzytelności ma miejsce zwykłego pobytu.

\subsection{Przelew wierzytelności pieniężnych złożonych na rachunku w instytucji kredytowej oraz wierzytelności $\mathrm{z}$ instrumentu finansowego}

Przechodząc zatem do przedstawienia rozwiązań szczególnych objętych projektem rozporządzenia, należy wskazać, że zgodnie z jego art. 4 ust. 2, w przypadku cesji a), gotówki złożonej na rachunku w instytucji kredytowej" oraz b) wierzytelności z instrumentu finansowego, skutki przelewu wierzytelności wobec osób trzecich podlegają prawu właściwemu dla przenoszonej wierzytelności ${ }^{26}$. Pierwsza grupa szczegółowo opisana w projekcie obejmuje przeniesienie środków pieniężnych w dowolnej walucie, złożonych na rachunku w instytucji kredytowej, tj. podmiotu, którego działalność polega na przyjmowaniu depozytów lub innych funduszy podlegajacych zwrotowi od klientów oraz na udzielaniu kredytów na swój własny rachunek (w tym oddziału takiego podmiotu, który ma siedzibę na terenie Unii Europejskiej lub poza jej granicami, jeżeli od-

${ }^{26}$ Zob. też A. Dickinson: Tough Assignments..., s. 339; P. Mankowski: Der Kommissionsvorschlag..., s. 495-497; H. Kronke: Assignment of Claims and Proprietary Effects: Overview of Doctrinal Debate and the EU Commission's Proposal, Oslo Law Review 2019, Nr 1, s. 16; G. Cuniberti: La proposition de règlement..., s. 797; D. Einsele: Die Drittwirkung..., s. 480. 
dział znajduje się na terenie Unii). Druga kategoria, znajdująca szczególne unormowanie, to cesje wierzytelności wynikajaccych z instrumentów finansowych wskazanych w załączniku ${ }^{27}$ do dyrektywy Parlamentu Europejskiego i Rady 2014/65/UE z dnia 15 maja 2014 r. w sprawie rynków instrumentów finansowych oraz zmieniająca dyrektywę 2002/92/WE i dyrektywę 2011/61/UE ${ }^{28}$. Skuteczność przelewu obu rodzajów wierzytelności wobec osób trzecich poddana zostaje zatem prawu, któremu one (tj. przenoszone wierzytelności) podlegają ${ }^{29}$. Rozwiązanie to nawiąuje do dotychczasowego sposobu określania miarodajnego dla omawianego

${ }^{27}$ W sekcji C załącznika I do dyrektywy Parlamentu Europejskiego i Rady 2014/65/ UE z dnia 15 maja $2014 \mathrm{r}$. w sprawie rynków instrumentów finansowych oraz zmieniająca dyrektywę 2002/92/WE i dyrektywę 2011/61/UE wskazano następujące typy instrumentów finansowych: a) zbywalne papiery wartościowe; b) instrumenty rynku pieniężnego; c) jednostki uczestnictwa w przedsiębiorstwach zbiorowego inwestowania; d) transakcje opcyjne, transakcje typu futures, swap, kontrakty terminowe typu forward oraz wszelkie inne kontrakty pochodne dotyczące papierów wartościowych, instrumentów dewizowych, stóp procentowych lub oprocentowania, uprawnień do emisji lub innych instrumentów pochodnych, indeksów finansowych lub środków finansowych, które można rozliczać fizycznie lub w środkach pieniężnych; e) transakcje opcyjne, transakcje typu futures, swap, kontrakty terminowe typu forward oraz wszelkie inne kontrakty pochodne dotyczące towarów, które muszą być rozliczane w środkach pieniężnych lub które moga być rozliczane w środkach pieniężnych według uznania jednej ze stron, w przypadku innym niż niedotrzymanie warunków lub innego rodzaju zdarzenie skutkujące rozwiązaniem kontraktu; f) transakcje opcyjne, transakcje typu futures, swapy oraz wszelkie inne kontrakty pochodne dotyczące towarów, które można rozliczać fizycznie, pod warunkiem że podlegają one obrotowi na rynku regulowanym, MTF lub OTF, z wyjątkiem produktów energetycznych sprzedawanych w obrocie hurtowym, stanowiacych przedmiot obrotu na OTF, które muszą być rozliczane fizycznie; g) transakcje opcyjne, transakcje typu futures, swap, kontrakty terminowe typu forward oraz wszelkie inne kontrakty pochodne dotyczące towarów, które można rozliczać fizycznie oraz które nie zostały wymienione w inny sposób pod lit. f) powyżej i które nie są przeznaczone do celów handlowych i wykazują właściwości innych pochodnych instrumentów finansowych; h) instrumenty pochodne dotyczace przenoszenia ryzyka kredytowego; i) kontrakty finansowe na transakcje różnicowe; j) transakcje opcyjne, transakcje typu futures, swapy, kontrakty terminowe typu forward oraz wszelkie inne kontrakty pochodne odnoszace się do stawek klimatycznych, opłat przewozowych lub stóp inflacji lub innych urzędowych danych statystycznych, które muszą być rozliczane w środkach pieniężnych lub można rozliczać $\mathrm{w}$ środkach pieniężnych według uznania jednej ze stron w przypadku innym niż niedotrzymanie warunków lub innego rodzaju zdarzenia skutkującego rozwiązaniem kontraktu, a także wszelkiego rodzaju inne kontrakty pochodne dotyczące aktywów, praw, zobowiązań, indeksów oraz środków niewymienionych gdzie indziej w tej sekcji, które wykazują właściwości innych pochodnych instrumentów finansowych, uwzględniając, między innymi, czy podlegają one obrotowi na rynku regulowanym, OTF lub MTF; k) uprawnienia do emisji obejmujacce dowolne jednostki uznane za spełniające wymogi dyrektywy 2003/87/WE (system handlu uprawnieniami do emisji).

${ }^{28}$ Dz.U. L 173 z 12.06.2014, s. 349-496.

${ }^{29}$ D. Einsele: Die Drittwirkung..., s. 480. 
zakresu statutu (stosowany tu łącznik dawniej uważany był za regułę ogólną) i ma na celu sprostanie potrzebom podmiotów dokonujących cesji tego rodzaju wierzytelności, jak również sprzyja zachowaniu stabilności i sprawności funkcjonowania rynków finansowych. Podnosi się w szczególności, że sięgnięcie $\mathrm{w}$ tych przypadkach do prawa, któremu podlega przenoszona wierzytelność (np. prawa właściwego dla umowy łączącej posiadacza rachunku bieżącego z bankiem) zapewnia większą przewidywalność prawa, jakiemu poddano skuteczność cesji wobec osób trzecich ${ }^{30}$. Co do zasady bowiem wierzytelność posiadacza konta bankowego w odniesieniu do sumy pieniężnej złożonej na rachunku bankowym (albo też wierzytelność wynikająca $\mathrm{z}$ instrumentów finansowych) podlega prawu państwa, w którym bank (instytucja finansowa) ma swoją siedzibę (jako prawo wybrane przez strony lub wskazane poprzez łaczniki o charakterze obiektywnym) ${ }^{31}$. Słabość wskazanego rozwiązania ujawni się wówczas, gdy strony umowy rachunku bankowego lub umowy odnoszacej się do danego instrumentu finansowego odejdą od zakładanego, schematycznego modelu postępowania i korzystając z kolizyjnoprawnej autonomii woli stron, dokonaja dla swej umowy wyboru innego prawa, jako właściwego. Wówczas bowiem osoby trzecie - zważywszy m.in. na tajemnicę bankowa - będą miały błędne przekonanie o miarodajnym statucie dla skuteczności przelewu wobec nich ${ }^{32}$.

\subsection{Sekurytyzacja}

Drugi wyjątek od reguły podstawowej, która zostanie omówiona w dalszej kolejności, dotyczy prawa właściwego dla skutków przelewu wierzytelności wobec osób trzecich, dokonanego w ramach sekurytyzacji. Jedynie w celu uwypuklenia specyfiki zagadnienia warto wskazać, że sekurytyzacja jest mechanizmem pozwalajacym na refinansowanie puli wierzytelności danego przedsiębiorcy (inicjującego) poprzez ich przeniesienie na rzecz innego podmiotu (celowego), który na tej bazie emituje papiery wartościowe na rynku kapitałowym na rzecz potencjalnych inwestorów ${ }^{33}$. Mechanizm ten, w połączeniu z korzystnymi rozwiązaniami podatkowymi oraz konstrukcji podmiotu celowego, chroniącej go przed upadłością, pozwala na tańsze niż bankowe finansowanie działalności i ograniczenie kosztów jednostki inicjującej.

\footnotetext{
${ }^{30}$ H. Kronke: Assignment of Claims..., s. 16.

${ }^{31}$ Ibidem.

${ }^{32}$ D. Einsele: Die Drittwirkung..., s. 480.

${ }^{33}$ G. Cuniberti: La proposition de règlement..., s. 798.
} 
W odniesieniu do skuteczności przelewu wierzytelności wobec osób trzecich w ramach sekurytyzacji projekt rozporządzenia dopuszcza, by zbywca (podmiot inicjujacy) oraz nabywca (podmiot celowy) dokonali wyboru prawa przenoszonych wierzytelności jako prawa właściwego dla skutków ich cesji wobec osób trzecich ${ }^{34}$. W przypadku gdy do takiego ograniczonego wyboru prawa by nie doszło, miarodajnym statutem stałoby się prawo miejsca zwykłego pobytu zbywcy ${ }^{35}$. Wybór prawa może być dokonany wyraźnie w umowie cesji w ramach sekurytyzacji albo też $\mathrm{w}$ odrębnej umowie ${ }^{36}$. Ważność materialna i formalna wyboru prawa podlega prawu wybranemu (art. 4 ust. $3 \mathrm{zd}$. 2).

W uzasadnieniu do wskazanej reguły kolizyjnej wskazuje się na potrzebę elastycznego podejścia do wyznaczania prawa właściwego dla skutków przelewu wierzytelności wobec osób trzecich w ramach sekurytyzacji, w celu zaspokojenia potrzeb wszystkich podmiotów korzystających z tego mechanizmu i wzmocnienia rozwoju rynku sekurytyzacji transgranicznych, także z uwzględnieniem mniejszych podmiotów gospodarczych ${ }^{37}$. Jeżeli zatem strony nie dokonają wyboru prawa, a najczęściej takiej postawy będzie można oczekiwać od drobniejszych podmiotów inicjujących, w portfelach których mogą się znaleźć wierzytelności podlegające różnym prawom, do skutków przelewu wierzytelności wobec osób trzecich znajdzie zastosowanie prawo miejsca zwykłego pobytu zbywcy. Natomiast dużym graczom rynkowym, którzy mają możliwość — jako podmioty inicjujące - podzielić swoje pakiety wierzytelności według kryterium prawa, któremu one podlegaja, i dokonywać sekurytyzacji w taki sposób, by w danym pakiecie wszystkie wierzytelności przenoszone na podmiot celowy podlegały prawu tego samego państwa, może zależeć na tym, by poddać skuteczność cesji w ramach sekurytyzacji prawu przenoszonych wierzytelności ${ }^{38}$. Z drugiej strony, gdy takim dużym podmiotem jest jednostka celowa, pozyskujacca wierzytelności od wielu przedsiębiorców inicjujących, posiadających siedziby w różnych państwach, odejście od zasady, zgodnie z którą ocena skuteczności cesji wobec osób trzecich podlega prawu miejsca zwykłego pobytu zbywcy, zwiększa szanse na utrzymanie jednolitego statutu dla wszystkich transakcji. W obu przypadkach art. 4 ust. 3 projektu rozporządzenia pozwala na poddanie

${ }^{34}$ A. Dickinson: Tough Assignments..., s. 339. Krytycznie propozycję tę ocenia m.in. P. Mankowski: Der Kommissionsvorschlag..., s. 497-499; D. Einsele: Die Drittwirkung..., s. 480-481.

${ }^{35}$ G. Cuniberti: La proposition de règlement..., s. 798.

${ }^{36}$ H. Kronke: Assignment of Claims..., s. 16.

${ }^{37}$ G. Cuniberti: La proposition de règlement..., s. 798.

${ }^{38}$ Ibidem. 
skuteczności przelewu takich wierzytelności prawu jednego państwa, tj. temu, któremu podlegaja przenoszone wierzytelności.

Opisany powyżej wyjątek, odnoszacy się do cesji dokonywanych w ramach sekurytyzacji, a dopuszczajacy poddanie ich skuteczności wobec osób trzecich prawu właściwemu dla przenoszonych wierzytelności, odpowiada praktyce, która obecnie, z powodzeniem, stosują instytucje finansowe. Nasuwa się jednak pytanie, na ile - kosztem pewności obrotu, jaką zapewnia stosowanie dla skuteczności przelewu wobec osób trzecich prawa miejsca zwykłego pobytu cedenta - warto szczególnie chronić interesy podmiotów z rynku finansowego. Czy te potrzeby są na tyle istotne, by zasadę ogólną przyjętą w projekcie rozporządzenia dla nich korygować?

Jak zasygnalizowano już wcześniej, omówionym regulacjom szczególnym, przewidującym wyjątki od zasady właściwości prawa miejsca zwykłego pobytu zbywcy do oceny skuteczności przelewu wierzytelności wobec osób trzecich, towarzyszy reguła kolizyjna (swego rodzaju norma drugiego stopnia) $)^{39}$, rozwiązująca konflikt pierwszeństwa między nabywcami tej samej wierzytelności w przypadku, gdy skutki jednego z przelewów wobec osób trzecich podlegają prawu państwa, w którym zbywca ma miejsce zwykłego pobytu, a skuteczność innych cesji względem tychże podmiotów podlega prawu właściwemu dla przenoszonej wierzytelności ${ }^{40}$. Wówczas, zgodnie z art. 4 ust. 4 projektu rozporządzenia, za miarodajne dla rozstrzygnięcia tej kolizji należy uznać reguły wynikające z prawa właściwego dla skutków wobec osób trzecich tej cesji, która jako pierwsza stała się względem nich skuteczna, zgodnie $\mathrm{z}$ prawem właściwym dla danego przelew $\mathrm{u}^{41}$. W przypadku zatem, gdy w odniesieniu do tej samej wierzytelności dokonano więcej niż jednej cesji, a przy tym zgodnie z projektem rozporządzenia skuteczność wobec osób trzech jednej z nich podlega prawu właściwemu dla przenoszonej wierzytelności, a innej - prawu państwa, w którym zbywca ma miejsce zwykłego pobytu i jednocześnie miarodajne w tym względzie reguły merytoryczne prowadzą do rozstrzygnięć uniemożliwiających ustalenie, któremu z konkurujących podmiotów przysługuje pierwszeństwo, gdyż wchodzące $\mathrm{w}$ grę merytoryczne regulacje wskazują inną osobę, należy badać, w odniesieniu do każdego z przelewów, z jaką chwila stał się on skuteczny względem osób trzecich (zgodnie z prawem dla jego skuteczności wobec osób trzecich właściwym) ${ }^{42}$. Tak uzyskane wyniki trzeba

${ }^{39}$ Zob. szerzej A. Dickinson: Tough Assignments..., s. 343.

${ }^{40}$ Ibidem, s. 339.

${ }^{41}$ Zob. D. Einsele: Die Drittwirkung..., s. 481; H. Kronke: Assignment of Claims..., s. 17 .

${ }^{42}$ H. Kronke: Assignment of Claims..., s. 17. 
następnie porównać, a konflikt pierwszeństwa między nabywcami tej samej wierzytelności, będący pochodną dokonania więcej niż jednej cesji, której skuteczność wobec osób trzecich oceniana jest na podstawie innego prawa, należy rozstrzygnąc zgodnie z systemem prawnym właściwym dla skuteczności wobec osób trzecich tego przelewu wierzytelności, który jako pierwszy okazał się skuteczny względem nich ${ }^{43}$. Nie musi to być co oczywiste - cesja, w odniesieniu do której umowa została zawarta wcześniej. O skuteczności przelewu wobec osób trzecich mogą bowiem decydować inne okoliczności niż chwila zawarcia umowy (np. zawiadomienie dłużnika o przelewie, wpis cesji do odpowiedniego rejestru albo ogłoszenie o takim wpisie) $)^{44}$. Niestety, stosowanie wskazanej reguły kolizyjnej drugiego stopnia może okazać się problematyczne w przypadku bardziej złożonych stanów faktycznych (przykładowo - w odniesieniu do wielokrotnych przelewów tej samej wierzytelności dokonywanych przez podmioty, które uprzednio zawarły umowy cesji z pierwotnym wierzycielem [dążącym do przeniesienia tej wierzytelności na rzecz więcej niż jednego nabywcy] $)^{45}$. Projekt rozporządzenia nie udziela bowiem odpowiedzi na pytanie, czy w tym łańcuchu transakcji należy brać pod uwagę jedynie aktualny konflikt pomiędzy zainteresowanymi podmiotami, czy też trzeba uwzględniać także transakcje dokonane pomiędzy podmiotami zawierającymi umowy z pierwotnym wierzycielem ${ }^{46}$. W celu zapewnienia bezpieczeństwa obrotu jedynie ta druga droga wydaje się właściwa, choć - paradoksalnie - nie ułatwi to procesu ustalania pierwszeństwa zainteresowanych podmiotów względem przenoszonej wierzytelności.

\subsection{Reguła ogólna}

W przypadku gdy brak jest podstaw do zastosowania regulacji szczególnych omówionych powyżej, ocena skuteczności przelewu wierzytelności wobec osób trzecich powinna być dokonywana na podstawie prawa wskazanego przez normę ogólną, tj. prawa państwa, w którym cedent ma

${ }^{43}$ G. Cuniberti: La proposition de règlement..., s. 796.

${ }^{44}$ Ibidem.

${ }^{45}$ Dla zilustrowania problemu można posłużyć się następującym przykładem. Wierzyciel A zawiera umowę przelewu najpierw z podmiotem B, a następnie z C. Po tych transakcjach $\mathrm{B}$ dąży do przeniesienia wierzytelności na rzecz $\mathrm{D}$ i E, a $\mathrm{C}$ zawiera umowę cesji z podmiotem $\mathrm{F}$, a $\mathrm{E}$ z jeszcze inną osoba - G... Na pojawiające się w takim przypadku trudności zwraca uwagę m.in. A. Dickinson: Tough Assignments..., s. 337.

${ }^{46}$ D. Einsele: Die Drittwirkung..., s. 481. 
miejsce zwykłego pobytu w miarodajnej chwili (art. 4 ust. 1 projektu ${ }^{47}$. Co do zasady zatem, merytoryczne reguły odnoszace się do kwestii pierwszeństwa danego podmiotu do przenoszonej wierzytelności względem innych osób wywodzone będą z regulacji wskazanej łącznikiem personalnym zbywcy. Pamiętać przy tym trzeba, że zgodnie z art. 2 lit. f) projektu rozporządzenia „miejsce zwykłego pobytu” w odniesieniu do spółek i innych jednostek organizacyjnych, posiadających osobowość prawną lub jej nieposiadających, oznacza miejsce, w którym znajduje się siedziba ich głównego organu zarządzającego, natomiast w odniesieniu do osoby fizycznej działajaccej w ramach prowadzonej przez nią działalności gospodarczej - miejsce głównego jej przedsiębiorstwa ${ }^{48}$.

W projekcie rozporządzenia próbowano także rozstrzygnąć problem, jaki powstanie w przypadku zmiany przez cedenta miejsca zwykłego pobytu w okresie pomiędzy dokonaniem dwóch przelewów tej samej wierzytelności na różnych cesjonariuszy. Wówczas kwestia pierwszeństwa jednego nabywcy względem drugiego poddana będzie prawu miejsca zwykłego pobytu zbywcy w chwili dokonania tego przelewu, który jako pierwszy stał się skuteczny w odniesieniu do osób trzecich zgodnie z miarodajnym w tym względzie statutem (art. 4 ust. 1 zd. 2 projektu) ${ }^{49}$. Wskazana reguła kolizyjna drugiego stopnia podobna jest zatem do tej, która rozstrzyga kwestię pierwszeństwa między nabywcami tej samej wierzytelności w przypadku, gdy skutki jednej cesji wobec osób trzecich podlegaja prawu państwa, w którym zbywca ma miejsce zwykłego pobytu, a skuteczność innych przelewów - prawu właściwemu dla przenoszonej wierzytelności ${ }^{50}$. Tu zatem również należy porównać, która z konkurujacych cesji jako pierwsza stała się skuteczna wobec osób trzecich ${ }^{51}$ i prawo rozstrzygające o tej skuteczności stanie się właściwe do oceny pierwszeństwa pomiędzy konkurującymi nabywcami wierzytelności będącej przedmiotem tych przelewów. Co oczywiste, zabieg taki należy rozszerzyć o kolejną transakcję, jeżeli w danym stanie faktycznym zbywca zawarł jeszcze jedną umowę przelewu, a o pierwszeństwo do przenoszonej wierzytelności pretenduje więcej niż dwóch potencjalnych nabywców ${ }^{52}$.

Wskazane w art. 4 ust. 1 projektu rozporządzenia powiązanie kolizyjne w odniesieniu do skuteczności przelewu wierzytelności wobec osób

${ }^{47}$ G. Cuniberti: La proposition de règlement..., s. 794; P. Mankowski: Der Kommissionsvorschlag..., s. 491-494; D. Einsele: Die Drittwirkung..., s. 479.

${ }^{48}$ D. Einsele: Die Drittwirkung..., s. 479.

${ }^{49}$ A. Dickinson: Tough Assignments..., s. 343.

${ }^{50}$ H. Kronke: Assignment of Claims..., s. 17.

${ }^{51}$ Co do pojawiających się na tym tle trudności zob. w szczególności A. Dickinson: Tough Assignments..., s. 343-344.

${ }^{52}$ Zob. uwagi A. Dickinson: Tough Assignments..., s. 344-345. 
trzecich, opierające się na łączniku personalnym cedenta, zyskiwało swoich zwolenników już od dłuższego czasu ${ }^{53}$; było ono także rozważane na etapie przygotowywania polskiej ustawy o prawie prywatnym międzynarodowym z $2011 \mathrm{roku}^{54}$. Jakie zatem argumenty przemawiaja za takim kryterium powiązania, odbiegającym od wcześniej powszechnie aprobowanych rozwiązań, hołdujących w tym zakresie - co do zasady — prawu, któremu podlega przenoszona wierzytelność?

Początkowo, z dużym oporem torowała sobie drogę przyjęta w art. 4 ust. 1 projektu rozporządzenia koncepcja poddania problematyki szeroko rozumianych skutków rozporządzających przelewu prawu państwa, w którym zbywca wierzytelności ma miejsce zwykłego pobytu. Wynikało to stąd, że cesja była utożsamiana li tylko z podmiotowym przekształceniem stosunku prawnego. Jednocześnie jako aksjomat przyjmowano, że wszelkie zmiany, jakie miałyby się dokonywać $\mathrm{w}$ ramach danej relacji zobowiązaniowej, podlegać powinny prawu, któremu to zobowiązanie zostało poddane. Jeżeli jednak na przelew wierzytelności spojrzymy przez pryzmat obrotu gospodarczego i dostrzeżemy w nim mechanizm, dzięki któremu dochodzi do transferu aktywów z majątku jednego podmiotu na rzecz innego, o wiele łatwiej będzie uwolnić się od wskazanego powyżej aksjomatu i skorzystać z rozwiązania kolizyjnego posiadajacego zalety trudne do przecenienia. To ostatnie spostrzeżenie jest szczególnie istotne w odniesieniu do osób trzecich niebędących strona stosunku zobowiazaniowego, z którego pochodzi przenoszona wierzytelność. Dla tychże podmiotów stanowi ona bowiem jedynie określoną wartość majątkowa, niezależnie od tego, jakiemu prawu podlega ${ }^{55}$.

Nie ulega watpliwości, że ustalenie miejsca zwykłego pobytu cedenta jest przez zainteresowane podmioty o wiele prostsze, niż określenie pra-

${ }^{53}$ E.-M. Kieninger: Der Statut der Forderungsabtretung im Verhältnis zu Dritten, RabelsZ 1998, Nr 3, s. 702-710; E.-M. Kieninger: Brussels I, Rome I and questions relating to assignment and subrogation, W: Enforcement of International Contracts in the European Union. Convergence and divergence between Brussels I and Rome I. Red. J. Meeusen, M. Pertegás, G. Straetmans. Antwerpia-Oksford-Nowy Jork 2004, s. 383-386; W. Kurowski: Przelew wierzytelności..., s. 137-143; P. Lagarde: Retour sur la loi applicable..., s. 425-426; A. Wowerka: Prawo wtaściwe..., s. 148-149, 157; A. Wowerka: Przelew wierzytelności..., s. 44-45; W. Kurowski: Prawo właściwe..., s. 162.

${ }^{54}$ Zob. projekt ustawy o prawie prywatnym międzynarodowym z 9.10.2006 r. ogłoszony drukiem w PPPM 2007, Nr 1, s. 115-131; zob. także A. Kozakiewicz, W. Kurowski: Co dalej z kodyfikacja prawa prywatnego międzynarodowego w Polsce?, „Kwartalnik Prawa Prywatnego" [KPP] 2003, Nr 4, s. 932-933; W. Kurowski: Przelew wierzytelności..., s. 249-251; M. Pazdan: O projekcie nowej ustawy o prawie prywatnym międzynarodowym, PPPM 2007, Nr 1, s. 18.

${ }^{55}$ W. Kurowski, W: System prawa prywatnego. Tom 20B. Prawo prywatne międzynarodowe, Red. M. Pazdan. Warszawa 2015, s. 388-389. 
wa, któremu podlega przelewana wierzytelnośćs6. Dzięki temu łatwiejsze staje się zatem wskazanie miarodajnego dla skuteczności przelewu wierzytelności wobec osób trzecich prawa, co sprzyja pewności obrotu ${ }^{57}$. Trudno także kwestionować twierdzenie, że miejsce zwykłego pobytu zbywcy jest powiazzaniem stabilnym, a jego zmiana bardziej widoczna dla innych podmiotów niż w przypadku łącznika odwołującego się do prawa właściwego dla stosunku zobowiązaniowego będącego źródłem przelewanej wierzytelność. Wskazywana tu stabilność jest wartością niezmiernie istotna dla podmiotów uczestniczących w obrocie gospodarczym, wzmacniając ich poczucie bezpieczeństwa ${ }^{58}$. Osoby trzecie nie mają bowiem skutecznych narzędzi do ustalenia prawa właściwego dla przelewanej wierzytelności, które - co więcej — może być modyfikowane (praktycznie do chwili cesji) przez strony stosunku prawnego, z którego ona wynika.

Poddanie skuteczności cesji względem osób trzecich prawu miejsca zwykłego pobytu zbywcy rozwiąże także praktyczne problemy ze wskazaniem miarodajnego statutu w przypadku cesji globalnej ${ }^{59}$ lub przelewu wierzytelności przyszłych ${ }^{60}$. W odniesieniu do tych transakcji poszukiwanie innego systemu prawnego, któremu omawiane zagadnienie miałoby podlegać jest albo bardzo utrudnione, albo wręcz niemożliwe. Konieczne byłoby wówczas stosowanie zabiegów, które pozwoliłyby na dopasowanie tej reguły kolizyjnej do tak ukształtowanego stanu faktycznego, co często razi sztucznościa. W kontekście poszukiwania zalet danego łącznika, wykorzystywanego na potrzeby ustalenia miarodajnego statutu, nie może także umknać uwadze fakt, że niektóre merytoryczne systemy prawne łączą skuteczność przelewu wierzytelności wobec osób trzecich $\mathrm{z}$ wpisem cesji do odpowiedniego rejestru lub z ogłoszeniem o takim wpisie. W przypadku poddana problematyki szeroko rozumianych skutków rozporządzających cesji prawu państwa, w którym zbywca ma miejsce zwykłego pobytu, będzie ono także właściwe dla samej procedury wpisu przelewu do rejestru lub publikacji ogłoszenia o cesji. Te ostatnie podlegaja bowiem legis fori processualis.

${ }^{56}$ P. Lagarde: Retour sur la loi applicable..., s. 425-426; M.P. Zachariasiewicz: Zmiany w unormowaniu..., s. 136-137; G. Cuniberti: La proposition de règlement..., s. 794 .

${ }^{57}$ Zob. D. Einsele: Die Drittwirkung..., s. 479.

${ }^{58}$ Zob. w tym duchu E. Rabel: The Conflict of Laws. A Comparative Study, Nr 3, Special Obligations: Modification and Discharge of Obligations. Chicago 1950, s. 432; M. Moshinsky: The Assignment of Debts..., s. 624; T.H.D. Struycken: The proprietary aspects..., s. 355; W. Kurowski: Przelew wierzytelności..., s. 246; W. Kurowski: Prawo wtaściwe..., s. 162. Zob. też R. Goode: The Assignment..., s. 305.

${ }^{59}$ G. Cuniberti: La proposition de règlement..., s. 795.

${ }^{60}$ W. Kurowski. W: System prawa prywatnego..., s. 390; G. Cuniberti: La proposition de règlement..., s. 795 . 
Ten sam argument, przemawiający za poddaniem skuteczności przelewu wierzytelności wobec osób trzecich prawu państwa, w którym cedent ma miejsce zwykłego pobytu, wypływa z odpowiednich regulacji odnoszących się do międzynarodowego postępowania upadłościowego ${ }^{61}$. Zgodnie bowiem $\mathrm{z}$ art. 7 ust. 2 lit. $\mathrm{m}$ ) rozporządzenia $\mathrm{w}$ sprawie postępowania upadłościowego, kwestia nieważności, zaskarżania lub względnej bezskuteczności czynności prawnych dokonanych z pokrzywdzeniem ogółu wierzycieli podlega prawu państwa wszczęcia postępowania upadłościowego (lex concursus) ${ }^{62}$. Nie ma zatem potrzeby dokonywania rozróżnienia kolizyjnoprawnej oceny skuteczności przelewu wierzytelności wobec osób trzecich w przypadku, gdy do cesji dochodzi w realiach grożącej (zaistniałej) upadłości zbywcy oraz w sytuacji, w której wobec cesjonariusza nie jest prowadzone postępowanie upadłościowe; będzie to zawsze ten sam system prawny ${ }^{63}$.

Na zakończenie warto także wskazać na jeszcze jedną zbieżność, jaka można osiągnąc dzięki poddaniu skuteczności przelewu wierzytelności wobec osób trzecich prawu państwa, w którym cedent ma miejsce zwykłego pobytu. Otóż w wielu przypadkach do cesji (jako czynności rozporządzającej) dochodzi w wykonaniu wcześniejszego zobowiązania wynikajaccego z umowy, która podlega swojemu odrębnemu statutowi. Jest on najczęściej wyznaczany w oparciu o reguły kolizyjne wypływające z rozporządzenia Rzym I, w szczególności jego art. 4. Przyjmując, że wierzytelność nie jest towarem (a zatem do jej sprzedaży nie znajduje zastosowania uzupełniająca reguła kolizyjna wynikająca $\mathrm{z}$ art. 4 ust. 1 lit. a) tego aktu), to prawem właściwym dla stosunku obligacyjnego pomiędzy zbywcą i nabywca wierzytelności będzie zazwyczaj prawo miejsca zwykłego pobytu podmiotu zobowiązanego do spełnienia świadczenia charakterystycznego dla tej umowy (art. 4 ust. 2 rozporządzenia Rzym I). Najczęściej, choć - co oczywiste - nie zawsze ${ }^{64}$, do głosu dojdzie tu zatem system prawny obowiązujaccy $\mathrm{w}$ miejscu zwykłego pobytu zbywcy wierzytelności.

Nie sposób także pominać faktu, że proponowane w projekcie rozporządzenia rozwiązanie kolizyjne jest zbieżne z unormowaniem przyjętym już w Konwencji ONZ o przelewie wierzytelności w handlu międzyna-

${ }^{61}$ Tak też G. Cuniberti: La proposition de règlement..., s. 794-795; D. Einsele: Die Drittwirkung..., s. 479.

${ }^{62}$ W. Kurowski. W: System prawa prywatnego..., s. 393; P. Mankowski: Der Kommissionsvorschlag..., s. 492.

${ }^{63}$ G. Cuniberti: La proposition de règlement..., s. 795.

${ }^{64}$ Przypadki poddania przelewu wierzytelności prawu państwa, w którym cesjonariusz ma miejsce zwykłego pobytu zostały przedstawione szerzej przez W. Kurowskiego. W: System prawa prywatnego..., s. 371-372. 
rodowym z 2001 roku $^{65}$. Mimo obecnie małego zainteresowania państw tą konwencja, ujednolicenie reguł w odniesieniu do skuteczności przelewu wobec osób trzecich pozwoliłoby na harmonizację prawa, zwiększając jego pewnośćc6.

\section{Zakres zastosowania prawa właściwego}

Tytuł rozporządzenia, którego projekt jest przedmiotem niniejszego omówienia, wyraźnie wyznacza zakres zastosowania prawa wskazanego na podstawie jego przepisów. Rzadko się przy tym zdarza, że regulacja kolizyjna rangi rozporządzenia dotyczy kwestii cząstkowej, jaką względem przelewu wierzytelności - jest jego skuteczność wobec osób trzecich. Dążąc do precyzji terminologicznej, w art. 2 lit. e) projektu rozporządzenia znalazła się definicja określenia: „skutki [cesji] wobec osób trzecich"67. W myśl wskazanej reguły, wyrażenie to oznacza skutki rozporządzające, tj. prawo nabywcy do wykonywania tytułu prawnego do wierzytelności przeniesionej na niego, w odniesieniu do innych nabywców lub uprawnionych z tej samej lub równoważnej funkcjonalnie wierzytelności, wierzycieli zbywcy i innych osób trzecich ${ }^{68}$. Innymi słowy,

${ }^{65}$ Tekst konwencji ONZ o przelewie wierzytelności w handlu międzynarodowym oraz jej tłumaczenie zostały opublikowane w KPP 2004, Nr 4, s. 1145-1193. Na temat konwencji zob. m.in. W. Kurowski: Przelew wierzytelności $w$ handlu międzynarodowym. Wprowadzenie, KPP 2004, Nr 4, s. 1133-1134; A.J. Bělohlávek: Rozporzadzenie Rzym I. Konwencja rzymska. Komentarz, t. 2. Warszawa 2010, s. 241-242; A. Krzykowski: Umowne zakazy przelewu wierzytelności (pacta de non cedendo) w obrocie krajowym $i$ międzynarodowym. Warszawa 2012, s. 114-115. Zob. także S.V. Bazinas: Lowering the cost of credit: the promise in the future UNCITRAL convention on assignment of receivables in international trade, „Tulane Journal of International and Comparative Law” 2001, Nr 9, s. 259-294; C. Walsh: Receivables financing and the conflict of laws: The UNCITRAL Draft Convention on the Assignment of Receivables in International Trade, „Dickinson Law Review” 2001, Nr 1, s. 159-204; H.C. Sigman, E.E. Smith: Toward facilitating cross-border secured financing and securitization: an analysis of the United Nations Convention on the Assignment of Receivables in International Trade, „Business Lawyer" 2002, Nr 2, s. 727-766; H.C. Sigman, F. Garcimartín, I.H. Cervantes: The United Nations Convention on the Assignment of Receivables in International Trade: A Comparative Analysis from Spanish and United States Perspectives, „Zeitschrift für Europäisches Privatrecht” 2006, Nr 2, s. 236-282.

${ }^{66}$ G. Cuniberti: La proposition de règlement..., s. 795.

${ }^{67} \mathrm{O}$ problemach dotyczacych kwalifikacji na tle projektu rozporządzenia zob. szerzej

A. Dickinson: Tough Assignments..., s. 340-341.

${ }^{68}$ Zob. szerzej W. Kurowski: Prawo wtaściwe..., s. 153-154. 
prawo wskazane na podstawie projektu rozporządzenia decyduje, który z konkurujących podmiotów może wykonywać uprawnienia wierzyciela względem dłużnika ${ }^{69}$. Pamiętać bowiem należy, że cesja powoduje zaburzenie dotychczasowego układu pomiędzy podmiotami konkurujacymi względem siebie o prawo do skorzystania z aktywa majątkowego, jakim jest wierzytelność. Co więcej, ta sama wierzytelność może być przedmiotem wielokrotnych przelewów dokonywanych przez tego samego cedenta na rzecz różnych podmiotów; zdarzają się także cesje następujące po sobie w krótkich odstępach czasu, gdzie w roli zbywcy występuja kolejni nabywcy. W obu opisanych powyżej przypadkach, jako kluczowe jawi się pytanie, który z podmiotów i z jaka chwila powinien być uznawany za uprawnionego. Warto przy tym wskazać, że projekt rozporządzenia nie definiuje pojęcia „osoba trzecia"70. W tym zakresie należy zatem sięgnąc do art. 14 ust. 2 rozporządzenia Rzym I, który - poprzez wyraźną regulację jego pozycji prawnej - wyłącza z zakresu tego określenia dłużnika przelewanej wierzytelności ${ }^{71}$. Biorąc powyższe pod uwagę, poza dłużnikiem, za osobę trzecią należy uznać każdy inny — niż sam cedent - podmiot, który jest zainteresowany tym, by uzyskać (zachować) uprawnienia do przenoszonej wierzytelności. Do tego grona trzeba zatem zaliczyć: wierzycieli zbywcy wierzytelności, wierzycieli nabywcy, innych nabywców (w przypadku rozporządzania wierzytelnością przez tego samego zbywcę na rzecz wielu podmiotów), następujących po sobie kolejnych nabywców, jeżeli dana wierzytelność jest przedmiotem wielokrotnego przelewu ${ }^{72}$. Za osobę trzecią należałoby także uznać syndyka masy upadłości zbywcy (inny podmiot, któremu w ramach postępowania upadłościowego lub sanacyjnego przypisuje się podobną do syndyka rolę). Jednakże w związku ze szczególną regulacją w rozporządzeniu upadłościowym właściwości prawa do oceny skuteczności czynności podjętych przez upadłego w ramach upadłości i w określonym czasie przed jej ogłoszeniem, problematyka ta nie jest wprost regulowana przez projekt rozporządzenia w sprawie prawa właściwego dla skutków przelewu wierzytelności wobec osób trzecich.

Autorzy omawianego projektu uznali jednak, że wskazanie zakresu zastosowania nowej regulacji poprzez zdefiniowanie określenia „skutki [cesji] wobec osób trzecich” jest niewystarczajace. Mimo zatem wprowa-

${ }^{69}$ D. Einsele: Die Drittwirkung..., s. 482

${ }^{70}$ Zob. A. Dickinson: Tough Assignments..., s. 340.

${ }^{71}$ D. Einsele: Die Drittwirkung..., s. 477.

${ }^{72}$ Zob. szerzej: W. Kurowski: Przelew wierzytelności..., s. 241-242; W. Kurowski: Zmiany podmiotowe w stosunku wynikajacym z kontraktu. W: System prawa handlowego. Tom 9. Międzynarodowe prawo handlowe, Red. W. Popiołek. Warszawa 2013, s. 770, a w szczególności W. Kurowski. W: System prawa prywatnego..., s. 387—388. 
dzenia syntetycznej definicji w art. 2 lit. e) projektu, jej rozwinięcie stanowiące jednocześnie wskazanie zakresu zastosowania prawa właściwego ustalonego na podstawie nowej regulacji — znalazło się w jej art. $5^{73}$. Prawu właściwemu dla skutków przelewu wierzytelności wobec osób trzecich podlegaja zatem w szczególności: a) wymogi zapewnienia skuteczności przelewu w odniesieniu do osób trzecich innych niż dłużnik, np. formalności związane z rejestracją lub ogłoszeniem; b) kwestia pierwszeństwa praw nabywcy przed prawami innego nabywcy tej samej wierzytelności; c) kwestia pierwszeństwa praw nabywcy przed prawami wierzycieli zbywcy; d) kwestia pierwszeństwa praw nabywcy przed prawami uprawnionego z przeniesienia umowy w odniesieniu do tej samej wierzytelności; e) kwestia pierwszeństwa praw nabywcy przed prawami uprawnionego $\mathrm{z}$ nowacji umowy względem dłużnika $\mathrm{w}$ odniesieniu do równoważnej wierzytelności.

Analiza cytowanego powyżej wyliczenia zagadnień wchodzących w zakres zastosowania prawa wskazanego przez reguły kolizyjne wynikajace z art. 4 projektu rozporządzenia - przykładowego, z samej natury norm kolizyjnych - prowadzi do wniosku, że prawo państwa, w którym zbywca ma miejsce zwykłego pobytu (wyjątkowo - prawo właściwe dla przenoszonej wierzytelności) decydować ma zarówno o zdarzeniach (środkach prawnych), dzięki którym przelew staje się skuteczny wobec osób trzecich (np. jako następstwo zawarcia ważnej umowy cesji, albo przyjmując zasadniczo konieczność przedsięwzięcia dodatkowych czynności - zawiadomienie dłużnika o przelewie, wpis cesji w odpowiednim rejestrze, ewentualnie ogłoszenie o takim wpisie), jak i o kategoriach podmiotów, których sprzeczne interesy w odniesieniu do przelewanej wierzytelności prawo to ma godzić, wskazując uprawnionego. Wydaje się jednak, że zabieg ten jest zbędny ${ }^{74}$. Nigdy bowiem nie budziło watpliwości w doktrynie, co należy rozumieć pod pojęciem „skuteczność przelewu wierzytelności wobec osób trzecich”, tj. o jakie kategorie podmiotów, których kwestię pierwszeństwa należy rozstrzygnąć, może chodzić, jak również - jakie zdarzenia prowadzą do skuteczności przelewu wobec osób trzecich.

${ }^{73}$ A. Dickinson: Tough Assignments..., s. 339-341. Zob. też H. Kronke: Assignment of Claims..., s. 11-13.

${ }^{74}$ Zob. szerzej A. Dickinson: Tough Assignments..., s. 341-343. 


\section{Podsumowanie}

Projekt rozporządzenia jest odpowiedzią na potrzebę wyraźnego unormowania kolizyjnoprawnej problematyki skuteczności cesji wobec osób trzecich. Nie ma bowiem racjonalnych argumentów, przemawiających za pozostawieniem tego zagadnienia do regulacji przez prawodawców krajowych. Taktyka, jaka przyjęto na etapie tworzenia rozporzadzenia Rzym I, zaowocowała rozbieżnościami pomiędzy poszczególnymi unormowaniami kolizyjnymi albo też - co gorsze - brakiem pewności co do prawa właściwego do oceny skuteczności cesji wobec osób trzecich (jeżeli prawodawcy krajowi nie uregulowali tej kwestii).

Watpliwości w odniesieniu do projektu rozporządzenia dotyczą przede wszystkim zasadności tworzenia wyłomów od wcześniej proponowanej jednolitej regulacji skuteczności przelewu wobec osób trzecich, opartej na łączniku miejsca zwykłego pobytu cedenta. Wydaje się, że autorzy proponowanego unormowania poddali się — po raz kolejny — presji nielicznej grupy zainteresowanych podmiotów ${ }^{75}$, czego efektem jest popsucie spójnego i logicznego rozwiązania kolizyjnego. Poza tym, zastrzeżenia budzi regulacja rozstrzygajaca potencjalne konflikty w przypadku wielokrotnych przelewów, przy których - w odniesieniu do ich skuteczności wobec osób trzecich - decydują systemy prawne wskazane przez różne łączniki, albo też podobne unormowanie, wskazujace prawo właściwe dla pierwszeństwa jednego nabywcy względem innego, w przypadku gdy zbywca wierzytelności zmienił $\mathrm{w}$ okresie pomiędzy przelewami miejsce zwykłego pobytu. Regulacje te, opierające się na normach kolizyjnych drugiego stopnia z art. 4 ust. 1 zd. 2 oraz ust. 4 projektu rozporządzenia, komplikują bowiem nadmiernie (albo - jak uważają niektórzy ${ }^{76}$ — wręcz uniemożliwiaja) ustalenie pierwszeństwa zainteresowanych podmiotów wobec danej wierzytelności w bardziej złożonych stanach faktycznych.

Można także postawić retoryczne pytanie, czy na unormowanie skuteczności cesji wobec osób trzecich trzeba było tak długo czekać, skoro proponowana przez autorów projektu rozporządzenia ogólna reguła kolizyjna odpowiada postulatom doktryny zgłaszanym od dawna?

${ }^{75}$ D. Einsele: Die Drittwirkung..., s. 482.

${ }^{76}$ A. Dickinson: Tough Assignments..., s. 345. 